\title{
INCORPORATING ACTIVE-READING HABIT IN ENGLISH CLASSES \\ OTHER THAN ENGLISH DEPARTMENT CLASSES
}

\author{
oleh Adi Sutrisno
}

Gadjah Mada University

\begin{abstract}
Abstrak
Kemampuan membaca teks berbahasa Inggris secara kritis sangat diperlukan oleh mahasiswa karena kemampuan tersebut menjadi prasarat penting bagi mahasiswa untuk menggali pengetahuan lebih dalam, yang pada umumnya masih ditulis dalam bahasa Inggris. Saat ini ketrampilan membaca teks bahasa Inggris secara kritis lazimnya hanya diberikan kepada mahasiswa Jurusan Sastra dan Bahasa Inggris. Dengan melihat kebutuhan yang sama, mahasiswa Jurusan non Sastra dan Bahasa Inggris pun perlu diberi bekal ketrampilan membaca kritis. Untuk itu, kelas bahasa Inggris untuk jurusan non Sastra dan Bahasa Inggris perlu diarahkan untuk menguasai ketrampilan membaca kritis dengan memperkenalkan 'active reading habit' kepada para mahasiswanya. Artikel ini mengulas tentang apa yang dimaksud dengan 'active reading habit' dan bagaimana mencangkokkannya dalam kelas bahasa Inggris untuk mahasiswa jurusan Non Sastra dan Bahasa Inggris.

Kata kunci: Teaching English to Students Other than English Department, active-reading habit, reading skills.
\end{abstract}

\section{A. Introduction}

It has been widely accepted that the capability of reading English texts is essential for university students as most of our knowledge is obtained through reading. A student with good reading skills in English may have better access to the information s/he needs than students with poor reading skills. It is mainly becauseing skills. It is mainly becauseng is mostly written in English. Unfortunately, this has not become our concern in our teaching. As asserted by Renandya (1995) and Djiwandono (1993), most of our classrooms activities engage teachers in testing students' comprehension rather than in teaching active-reading habit and good 
reading skills. The teachers often focus their teaching on the 'product' of reading, not on the 'process' of reading. As a result, students do not have active-reading habit and skills. This paper attempts to discuss the importance of introducing active-reading habit and reading skills to the non English department students. It also endeavors to reveal what constitute active-reading habit and how ta incorporate it in English classes.

According to Alderson and Urquhart (1984) problems of reading in a foreign language learning is not merely a language problem, but also reading problems. Thus, a reading class which focuses only on linguistic matters is not adequate to train students to be good readers. As such, the direction of a reading class should not only be driven to linguistic matters, but also to the skills of reading.

Skills of reading which should be introduced to the students may include previewing, skimming, scanning, and guessing. Previewing is an activity where a reader is trying to make some quick guess about what is in the text. Doing 'the previewing' before reading can make a big difference. A reader can get some ideas about what s/he will read. That way the reader will begin to process the information far more quickly. The reader will most likely be able to follow the writer's ideas better. Another skill, namely skimming is a high speed reading which may save lots of time, especially when a reader is required to read a long article. In this activity the reader only reads the words that will help him/her get the sense of the text. The reader only pays attention to the part which gives him/her clues to the contents of the articles. Besides previewing and skimming, there is still another skill namely scanning, which is the skill where a reader is engaged in a very high speed reading. By having questions in mind, a reader tries to find answer questioning his/her mind. S/he does not have to read every word. S/he only needs to read the word relating to what $\mathrm{s} /$ he is asking in his/her mind. The other skill, guessing is the skill which enables the reader to predict the meaning of the unfamiliar words. The importance of guessing is to construct the meaning from context. It is an important skill which must be trained to students, too.

DIKSI Vol.12, No.2, Juli 2005 
Training the reading skills to our students as outlined above can be quite hard if we do not have strong determination to give them to our students. It is because by teaching reading skills we are turning students' reading habit to a new one which is probably not common for some of them, especially those whose English is still relatively poor. As a consequence, teaching active-reading skills needs careful handling.

To cope with the problem, a teacher needs to start with interesting reading topics, as they often help motivate students to read further. As Goodman (1967), Smith (1971, 1985), and Nunan (1991) have said, the understanding of a text is often helped by the readers' interest in the content of the text and the background knowledge the readers might already have in their memory. This kind of understanding normally adopts what-so-called a top-down processing strategy. The strategy enables the readers to "reconstruct the writer's messages by bringing their background and cultural knowledge of the topic, and their knowledge of language system, in order to make meaning (Turner, 1994).

Steffensen's (1981 cited in Nunan, 1991) research report on the top-down model also supported the arguments above. He advocated that American did better on the text containing American cultural content and Indian did better on the text containing Indian cultural content when they were assigned to read the passages of which themes were American and Indian wedding. In short, the top-down processing strategy of reading is very much useful for the learners of English to help them accelerate their reading skills as well as their reading speed. Thus, it is apparent that top-down mode should be taken into consideration in teaching reading skills to our students.

However, it must be noted that though theoretically the topdown model is applicable to both L 1 and L2 learners (Nunan, 1991), the reading process in $\mathrm{L} 1$ will not be the same as in $\mathrm{L} 2$. The reason is as pointed out by Yorio, that

"the reader's knowledge of foreign language is not like that of native speaker; guessing or predicting ability necessary to pick up the correct cues is hindered by the imperfect knowledge of 
the language recollection of previous cues then is more difficult in a foreign language than in the mother tongue; and at all levels, and at all times, there is interference of native language" (Yorio, 1971)

Yorio implied that learners of English should increase their knowledge of the language and learn harder in order that they can free themselves from the possible influence coming from their $\mathrm{L} 1$. They need to be exposed to a variety of reading texts under the careful guidance of their teachers. It is thus imperative that the students be given opportunities to learn how to read texts using various techniques introduced by their teachers. Therefore, teachers need to enrich themselves with their teaching improvement.

This article is meant to introduce an active-reading habit, the objectives of which are to train the students to be able to read effectively.

\section{B. Rationales in Teaching Reading}

When discussing about what to teach, the nature of the subjects to teach should become the first consideration. Knowing the nature of the subject taught can help the teachers determine the problems encountered and their possible solutions. Therefore, at this very stage, it is important for us to know for certain what the nature of reading is.

Reading is often misunderstood as a passive skill. This is misleading, because when reading, the readers are not passively assimilating the information they are receiving. The readers are actively reconstructing the writer's messages. Hence, it is obvious that, by nature, reading is an active skill. It is necessary to note that in language studies, there are two kinds of skills which should be carefully understood by EFL teachers. They are productive and receptive skills. Productive skills belong to an ability to produce language, while receptive skills, by contrast, refer to an ability to receive messages. Seen from its nature, reading can be categorized as a receptive skill, as it deals with receiving messages. 
Yet, it is not necessary for teachers to confuse receptive with passive skills. Receptive skills have nothing to do with passive ones. Receptive skills are even active in nature. Thus, it is a good time for teachers to retrospect of what they have done, so far, with their techniques of teaching Reading. If they have never made their students be active readers, they now can question themselves wheter they have the right assumption about reading process or not. Take a look at the following technique in a common Reading class as criticized by Renandya (1995)

1. Teacher tells students to read a passage aloud or silently

2. Teacher provides corrective feedback in response to pupil errors

3. Teacher asks students to answer questions

4. Teacher explains the meaning of difficult words

What is wrong with the technique above? It seems that the teacher using the technique does not realize that $\mathrm{s} / \mathrm{he}$ is not 'teaching' reading. S/he is 'testing' a reading text, instead. In this situation, the students tend to be passive. This is against the nature of reading, where the active participation of the readers is given more room. The optimum result from this kind of reading is that the students only understand the content. That's all. This kind of technique will not enable the students to increase their reading skills.

The teacher who is aware of the importance of students' being active in decoding messages will not utilize the technique above. They will at least give the students ways to comprehend a text efficiently. Yet, it will be difficult to train students to understand a text efficiently if the teacher never creates an atmosphere where students can become active readers. Therefore, the first touch to make the students be able to read better and faster is by creating activities were students can be trained to actively reconstruct the messages being sent by the writer of the text. 


\section{Active Reading Habit and How to Incorporate it in an EFL Class}

Kennedy (1989) criticizes that many students tend to be 'passive' readers, both in their native language and in English. They only pay attention to the meaning of words; they often try to read word by word and do not think about the ideas they are reading. In order that students can be successful in their reading they must have an-active reading habit.

An-active reading habit according to Kennedy at al (1989) has the following characteristics: (1) always read with a purpose; (2) make a connection between the ideas they read and their lives; (30 draw conclusions about the ideas they read; (4) concentrate on what they read.

It can be seen from the suggestions that a good reading habit requires active participation in the part of the readers. The first characteristic means that a good reading habit encourages the readers to always actively think about the ideas they are reading, not the words. Good or active readers are not quiet. They are always 'talking' with the writer while reading. They are always asking themselves about the text, such as:

What is the main idea the author is trying to tell me?

What reasons does the author give to support his or her ideas?

What is the author going to tell me next?

What is the author's attitude toward his or her topic?

The second characteristic suggests that active readers make attempts to connect between the ideas they read and their lives, such as:

The information in this reading is similar to...

What the author says about this topic I can also use in .... 
The third one strongly suggests that when reading, active readers should form opinions or draw conclusions about the ideas they read. This skill is very important investment for the students' success at a college or university where English text books are widely available in their library. To draw conclusions, active readers may say to themselves:

I think I have to agree with this author because ..

I don't think the author really supports his or her ideas well because ......

I really disagree with what the author says because ......

The fourth advises that active readers always concentrate on the ideas presented in the text. They are also actively searching the answers of the questions they are asking. Even before the readers read the text, they have already got a question in mind, such as:

What subject is the author going to write about?

The following is an example of how an active reader is actively engaged in comprehending a text. The excerpt is adapted from Newbury House TOEFL Preparation Kit by Kennedy, et al (1989).

Photosynthesis, which means "putting together with light," is the process by which green plants and certain other organisms transform light energy into chemical energy. During photosynthesis in green plants, light energy is captured and used to convert water, carbon dioxide, and minerals into oxygen and energy rich organic compounds.

It would be impossible to overestimate the importance of photosynthesis in the maintenance of life on Earth. If photosynthesis ceased, there would soon be little food or other organic matter on earth. Most organisms would disappear, and in time the Earth's atmosphere would become exist under such conditions would be the chemosynthetic bacteria, which can 
utilize the chemical energy of certain inorganic compounds and thus are not dependent on the conversion of light energy.

Requirements for food, materials, and energy in a world where human population is rapidly growing have created a need to increase both the amount of photosynthesis and the efficacy of converting photosynthesis output into products useful to people. One response to these needs the so called 'Green Revolution' has achieved enormous improvements in agricultural yield through the use of chemical fertilizers, pest and plant disease control, plant breeding, and mechanized tilling, harvesting, and crop processing. This effect has limited severe famines to a few areas of the world despite rapid population growth, but it has not eliminated widespread malnutrition.

Before reading the text, an active reader has got a question in his mind "What is the text about? After reading the first lines, the reader might have an answer that the text is about the process of photosynthesis. Look at the following:

Photosynthesis, which means "putting together with light," is the process by which green plants and certain other organisms transform light energy into chemical energy.

It is necessary to note, that in most cases, the very first sentence gives the readers about the subject the writer is going to develop in the text (see Kennedy, 1989; Ballard and Clanchy, 1996). If the reader is familiar with the subject of the text, s/he may have background information about it. If so, the reader can utilize it to decode the messages since the meaning of the text does not only reside inside the text but also outside the text, namely the memory of the reader (Goodman, 1967; Smith 1994; Cambourne 1987 cited in Nunan, 1991, and Nunan, 1991). In the next step, an active reader normally thinks about what information the author is adding to what s/he already knows about photosynthesis. Let's read the rest of the first paragraph. 
During photosynthesis in green plants, light energy is captured and used to convert water, carbon dioxide, and minerals into oxygen and energy rich organic compounds

What is the purpose of this sentence? Why did the author write it to follow the first sentence? Does it tell his point of view? Does it tell what the author is going to say about photosynthesis? If the reader reads carefully, she might find out that the writer is actually giving the reader more information about photosynthesis. The author wants to make sure that the reader is aware of the process the author is talking.

Let's read the next sentence which begins a new paragraph

It would be impossible to overestimate the importance of photosynthesis in the maintenance of life on Earth

What does this sentence mean? Does it just give an information, or does it give an idea the author has about photosynthesis? The sentence suggests that the author is trying to give his/her view about the importance of photosynthesis. An active reader may expect that the sentences following it will be about details to support his/her idea.

Let's read the rest of this paragraph.

If photosynthesis ceased, there would soon be little food or other organic matter on earth. Most organisms would disappear, and in time the Earth's atmosphere would become exist under such conditions would be the chemosynthetic bacteria, which can utilize the chemical energy of certain inorganic compounds and thus are not dependent on the conversion of light energy.

What is the purpose of writing these sentences? Since the writer always writes with purpose, not just put words on paper, s/he is trying 
to give arguments upon his/her preceding statement. S/he is trying to convince that photosynthesis is necessary for life on Earth. What support does the writer give? Without photosynthesis, there would be no food; most organism (including humans) would die, and only tiny bacteria would be able to survive.

The example above shows how a good reader thinks about the ideas $\mathrm{s} /$ he is reading. This kind of active reading needs to be introduced by the teachers of English to their students. By introducing that habit, the teacher does not merely give his/her students tasks to read texts but also strategies to approach them. The difference between the two is obvious. Giving the students tasks to read texts only will merely result in students' understanding about the content of the texts; while giving them strategies to approach texts will yield both the students' ability to utilize efficient strategy to comprehend the texts and students' understanding about the contents of the text. In such a situation, teacher needs to be aware of the fact that $\mathrm{s} / \mathrm{he}$ is transferring the technical know-how to decode texts, besides transferring contents of the texts to his/her students. In other words, $\mathrm{s} /$ he is transferring the strategy of the study skills for the purpose of comprehending texts. Since the teacher is transferring a skill, s/he must be able to present it subtly and carefully so that the students can copy what the teacher exemplifies.

Introducing such a reading skill to students other than English department is not easy as the students have not normally got enough exposure to English reading, and the class size is often too large. The larger the size of an English class and the more heterogeneous, the more difficult for the teacher to handle it. The distraction which possibly comes from such a class has the potential to disrupt the teaching and learning process. To do so, the teacher needs to introduce the following method: 
- state tasks

- state the objectives

- of the activity
- provoke input

- help solve problems

encountered

\section{LEAD-IN $\rightarrow$ INSTRUCT $\rightarrow$ DISCUSS $\rightarrow$ ORGANIZE FEEEDBACK \\ - direct the discussion \\ - introduce techniques \\ - give examples \\ - elicit discussion \\ - learn how the students can go}

Why is the lead-in activity important to open the class activity? We must remember that the goal of teaching is to enable students to learn. Though the teacher's main task is to teach a lesson, it is never sufficient for him/her just to cling to it. The teacher must also consider students' mood. The reason is, when they come to class, their minds are probably still wandering away from the lesson. Some students may still be disturbed by what happened on the way to school, such as problems with family or room mat, with other traffic users, especially if they go by motorbikes, with his/her girl/boyfriend, etc. It is the time for the teacher to draw students' attention to point where s/he can gradually kick off the class.

The teacher will put him/herself at risk if sibe starts the class 'cold', simply by opening the text book, because his/her students are still not in a right mood for learning. Before presenting the actual lesson, the teacher needs to e involve them in some kind of activities that will lead them to the expected teaching and learning situation. This is what is normally called 'entering behavior' or 'lead-in' activity. The activity should be conducted in such a way that both teacher and students can be involved in what is happening in the classroom.

When the 'lead-in' stage has been accomplished, the teacher 'instructs'. It is where the students are told exactly what they should do (Harmer, 1994). The instructions given must be clear and logical. Clear and logical instructions may motivate students to complete the tasks set up by the teacher. 
After the instruction is set up and the students are ready to have a go, the teacher must immediately give a chance for the students to do the tasks, either individually or in pairs. It is better for the teacher to let the students do the activity without frequent interruption from him/her. The teacher should not worry with the quietness of the class. Remember, that being quiet does not mean passive. Quietness in the reading activity is needed as the students have to utilize all the skills they have learned from the teacher quietly. When the students have completed the reading task, the teacher can elicit discussion to make sure whether the students are on the right track or not. It is also necessary for the teacher to evaluate how far the students can reach the goal set in the syllabus.

The next step is provoking students' input. As the students become active readers, the teacher may expect questions from the students about the difficulty in their attempts to apply the skills they have learned. In this situation, the teacher must be cooperative and patient. The teacher cannot ignore the slow students, even if the number of them is not significant. It is wise for the teacher to always have commitment to give full attention to both slow and good students. To do this, the teacher must be patient. Without having the feeling of patience, the teacher will not be able to guide students no matter how good his/her teaching techniques are. The teacher also needs to record what's going on in the class so that s/he can evaluate the efficacy of his/her teaching techniques.

\section{Conclusion}

'Active reading' is an important habit which must be possessed not only by English department students but also by students other than English department. The reason is 'active reading' can help students excerpt the knowledge they need which is normally still written in English.

Active reading habit can be introduced to students other than English department by incorporating it in the teaching learning process. The incorporation can follow the suggestion proposed by Harmer (1994), started with lead-in activity, the function of which is to ease the transfer 
of the knowledge being directed to the students. After the students are ready to receive the knowledge, the teacher than gradually introduces 'the technical know-how' or 'strategy' to approach English texts critically. The introduction of 'the technical know-how' must be presented subtly as it involves delicacy in implanting a new habit to the students. By following Harmer's (1994) model, the teacher can help students to acquire how to decode English texts actively.

\section{BIBLIOGRAPHY}

Alderson, J.C. and Uquhart, A.H. (eds). 1984. Reading in a Foreign Language. London: Longman.

Ballard and Clanchy. 1996. Study Abroad: A Manual forAsian Students, Sydney : Longman.

Djiwandono, P. 1993. 'Developing EFL students' reading comprehension strategies', TEFLIN Journal, vol. 6 no. 1. pp. 48 - 68.

Goodman, K.S. 1967. 'Reading: A Psycholinguistic Guessing Game', Journal of Reading Behavior, vol 4, pp. 126135.

Harmer. 1994. The Practice of English Language Teaching. New York: Longman.

Kennedy, et al. 1989. The Newbury House TOEFL Preparation Kit:

Preparingfor the TOEFL. New York : Newbury House.

Nunan, D.1991. Language Teaching Methodology. International, New York : Prentice Hall.

Renandya, W. 1995. 'Are You Teaching or Testing Reading?' TEFLIN Journal, vol. VII, no. 1.

Smith, F. 1994. Understanding Reading, $5^{\text {th }}$ ed. Hillsdale, NJ : Lawrence ErlbaumAssociates.

Turner, L. 1994. Current Approach to Language Teaching Methodology:

Study Guide. Sydney : Deakin University.

Yorio, C.C. 1971. 'Some sources of Reading for Foreign Language Learners', Language Learning, vol. 21, pp. 107115. 